\title{
Penggunaan Media Game Matematika Online untuk Meningkatkan Kemampuan Representasi Matematis Siswa SMP Se-Kota Lhokseumawe
}

\author{
Andriani $^{1}$, Rika Silviani ${ }^{2}$, Lia Rista ${ }^{3}$, Cut Yuniza Eviyanti ${ }^{4}$ \\ 1,23,4 STKIP Bumi Persada Lhokseumawe, Jln. Medan-Banda Aceh Desa Alue Awe No. 59 Kota Lhokseumawe-Aceh \\ andrianihulwah@gmail.com
}

\begin{abstract}
This research aims to analyze the improvement of mathematical representation ability students who learning using online mathematics games media significantly better than conventionally of junior high school students in Lhokseumawe. The population was all junior high school students in the city Lhokseumawe. The Research sample was class VIII students at SMPN Negeri 2 Lhokseumawe, SMP Negeri 3 Lhokseumawe, SMP Swasta Sukma Bangsa Lhokseumawe. Sample selection using random sampling class technique who were ramdomly selected as the experimental is learning using online mathematics games media and as a control class by ordinary learning. The research method is quasi experimental. The research instruments used form of representation test and observation sheet. Data analysis begins with a test of normality and homogenity, the data is analyzed using t-tests of the hypotheses that have been formulated. The research results obtained a significance value of 0.000 , this value is smaller than the value of $\alpha=0.05$, and the value of $t_{\text {count }}$ is 7.584 greater than $t_{\text {table }}$ is 1,9799 . The results showed that the improve of the mathematical representation ability which taught using online mathematics games media significantly better than students taught conventionally of junior high school students in Lhokseumawe.
\end{abstract}

Keywords: Online mathematics games, Mathematical representation ability

\begin{abstract}
Abstrak
Penelitian ini bertujuan untuk mengetahui peningkatan kemampuan representasi matematis siswa yang memperoleh pembelajaran dengan menggunakan media game matematika online lebih baik secara signifikan daripada siswa yang memperoleh pembelajaran konvensional. Populasi dalam penelitian ini adalah seluruh siswa SMP Sekota Lhokseumawe. Sampel Penelitian adalah kelas VIII SMPN Negeri 2 Lhokseumawe, SMP Negeri 3 Lhokseumawe, SMP Swasta Sukma Bangsa Lhokseumawe. Pemilihan sampel dengan menggunakan tehnik random sampling class, yakni dipilih secara acak sehingga terpilih kelas ekperimen yang mengikuti pembelajaran dengan game matematika online dan kelas kontrol yang mengikuti pembelajaran biasa. Penelitian ini menggunakan metode kuasi eksperimen. Pengumpulan data menggunakan instrumen penelitian berupa soal tes representasi dan lembar observasi. Analisis data diawali dengan uji normalitas dan homogenitas selanjutnya data dianalisis menggunakan uji-t untuk menguji hipotesis yang telah dirumuskan. Hasil penelitian diperoleh nilai signifikansi sebesar 0,000 , nilai tersebut lebih kecil dari nilai $\alpha=0,05$, dan nilai thitung adalah 7,584 lebih besar dari $t_{\text {tabel }}$ yaitu 1,9799. Karena nilai signifikansi lebih kecil dari $\alpha$ atau $t_{\text {hitung }}>t_{\text {tabel }}$, maka $\mathrm{H}_{0}$ ditolak dan $\mathrm{H}_{\mathrm{a}}$ diterima. Hal ini menunjukkan peningkatan kemampuan Representasi matematis siswa yang diajarkan dengan menggunakan media game matematika online lebih baik secara signifikan daripada siswa yang diajarkan secara konvensional di SMP Se-kota Lhokseumawe.
\end{abstract}

Kata kunci: Game Matematika Online, Kemampuan Representasi Matematis

Copyright (c) 2021 Andriani, Rika Silviani, Lia Rista, Cut Yuniza Eviyanti

$\triangle$ Corresponding author: Andriani

Email Address: andrianihulwah@gmail.com (Jl. Medan-Banda Aceh Desa Alue Awe No. 59 Kota Lhokseumawe)

Received 10 Desember 2020, Accepted 15 Maret 2021, Published 16 Maret 2021

\section{PENDAHULUAN}

Proses Pembelajaran disekolah disamping menggunakan buku pelajaran juga diharuskan kepada guru untuk menggunakan media yang bermanfaat untuk mempermudah siswa dalam menerima pelajaran dengan tanggap, praktis dan mudah dipahami oleh siswa. Penggunaan media digital (Hakim \& Sari, 2019) seperti Komputer dan Gadget sekarang ini sudah tidak asing lagi bagi 
siswa Sekolah Menengah Pertama (SMP), bahkan hampir semua kebutuhan primer dan sekunder, kebutuhan ekonomi dan pendidikan sudah disediakan dilayar digital sebagai fitur untuk memudahkan dalam kehidupan masyarakat seluruh dunia. Selaras dengan ini sektor pendidikan pun tidak kalah penting terhadap kebutuhan aplikasi digital khususnya pada mata pelajaran matematika, karena pelajaran matematika tergolong sulit dipahami siswa tanpa ada media yang digunakan pada saat proses pembelajaran. Persepsi matematika merupakan pelajaran relatif sulit sebagaimana diungkapkan oleh (Siregar, 2017) sementara disisi lain pelajaran matematika sangat dibutuhkan pada masa digital dan teknologi sekarang ini. Sejalan dengan ini (Patahuddin \& Rokhim, 2009) mengatakan bahwa peran guru sangat dibutuhkan untuk mengarahkan siswa supaya terjadi proses pembelajaran matematika yang menyenangkan dan mudah memahami materi matematika. Sehingga penggunaan media yang tepat merupakan salah satu upaya guru untuk mengatasi masalah ini yakni menggunakan Game matematika Online dalam proses pembelajaran matematika.

Game matematika online merupakan media pembelajaran yang diminati banyak siswa dan berperan penting dalam proses pengajaran bidang studi Matematika karena pelajaran matematika tergolong sulit dipahami siswa tanpa ada media yang digunakan pada saat proses pembelajaran. Sehingga Game matematika online dapat membantu mempermudah dan menyenangkan siswa dalam memahami materi Matematika (Hamidah \& Hakim, 2016). Sehingga peran guru dalam menyelesaikan masalah ini dengan menggunakan media pembelajaran yang sesuai dan tepat dalam proses pembelajaran matematika. Media pembelajaran yang sesuai dalam hal ini adalah game matematika online.

Game matematika Online merupakan salah satu media pembelajaran yang sesuai dengan tingkat intelektual seusia siswa SMP dan sangat digemari siswa sehingga menghasilkan sebuah media pembelajaran matematika yang menyenangkan serta memudahkan siswa dalam memahami materi ajar matematika (Hamidah \& Hakim, 2016). Game matematika online merupakan salah satu game yang menyediakan berbagai macam bentuk materi matematika yang dikemas dalam bentuk game. Game matematika online yang dimaksud terdapat pada URL: https://www.ixl.com. Sejalan dengan ini Andriani (Yanni, 2019) menjelaskan dengan menerapkan game matematika online, kemampuan memahami materi dan motivasi belajar matematika siswa lebih meningkat. Dalam penerapannya sebagai media pembelajaran memiliki beberapa fungsi yaitu dapat memperjelas materi pelajaran yang sulit dipahami menjadi mudah dipahami, lebih menarik perhatian siswa sehingga siswa menjadi termotivasi dalam belajar matematika, suasana belajar yang efektif dan menyenangkan siswa.

Peneliti telah melakukan observasi awal peneliti ke beberapa sekolah tingkat SMP Wilayah Kota Lhokseumawe yaitu SMP Negeri 2 Lhokseumawe, SMP Negeri 3 Lhokseumawe dan SMP Swasta Sukma Bangsa, peneliti mendapatkan informasi baik dari siswa maupun dari guru bidang studi matematika bahwa mayoritas siswa masih kesulitan dalam belajar beberapa materi matematika seperti materi statistika, dikarenakan beberapa faktor yakni siswa kesulitan dalam menyelesaikan masalahmasalah matematika siswa dalam belajar matematika. Kemampuan representasi matematis merupakan 
kemampuan mengkonstruk pemahaman dengan penalarannya serta mengkomunikasikannya melalui gambar, peta, tulisan dan sikap siswa sehingga memunculkan ide-ide matematika dengan jelas (Sabirin, 2017). Siswa yang memiliki kemampuan representasi matematis dapat ditandai dengan tindakan siswa yang berusaha memahami masalah matematika dengan cepat, teliti, logis dan menyelesaikannya dengan cara-cara yang mereka ketahui (Sulastri et al., 2017).

Pelajaran matematika bersifat abstrak dan algoritmik sementara siswa usia SMP tingkat perkembangan kecerdasannya masih sulit memahami abstrak sehingga dalam hal ini diperlukan inovasi guru dalam menerapkan pembelajaran efektif. Diantara inovasi yang dapat dilakukan guru dengan menerapkan media pembelajaran dalam proses belajar. Sejalan dengan ini (Ilyas et al., 2020) media pembelajaran mempunyai beberapa peranan yaitu dapat mengkonkretkan hal yang bersifat abstrak dan membantu siswa menjelaskan materi pelajaran yang sulit dipahami secara verbal. Sebagaimana yang dijelaskan (Andini \& Yunianta, 2018) dengan menggunakan media, siswa akan lebih menarik perhatiannya dan tidak mudah bosan dalam belajar, apalagi jika media tersebut digunakan berupa game. Jelas bahwa dengan menggunakan media siswa akan lebih kreatif dalam menyelesaikan masalah-masalah matematika (Abdillah \& Sudrajat, 2014).

Kelebihan game matematika online seperti dijelaskan (Khatimah et al., 2019); (Wibowo, 2020) bahwa siswa bebas mengambil keputusan dan menyelesaikan masalah matematika serta dapat menggunakan waktu yang singkat dan efisien, guru dapat mengevaluasi hasil kerja siswa melalui pengamatan langsung pada saat mengoperasikan game, siswa merasa senang dengan pembelajaran yang menerapkan game matematika online.

Kemampuan representasi matematis membangun belajar jadi bermakna serta membantu memperjelas atau memperluas ide matematika (Zhe, 2012). Representasi merupakan kemampuan dasar yang harus dimiliki siswa dalam menggunakan ide-ide matematika (Chen, 2016). Hal ini juga dijelaskan (Sabirin, 2017) bahwa kemampuan representasi menjadikan siswa mengkonstruk pemahaman dengan penalarannya serta mengkomunikasikan ke dalam ide-ide matematika yang jelas. Sejalan dengan ini (Rangkuti, 2013) representasi matematis merupakan instrumen bagi siswa untuk memahami pengetahuan matematika. Sehingga dari beberapa definisi tersebut dapat disimpulkan bahwa kemampuan representasi matematis siswa adalah pengungkapan, penjelasan ide-ide matematika dapat berupa tabel, gambar, rumus, ulasan kata-kata untuk menemukan suatu penyelesaian masalah matematika serta menunjukkan pemahamannya yang ditampilkan dalam bentuk lisan maupun tulisan, serta bahasa tubuh atau isyarat.

Penelitian ini merupakan pengembangan dari penelitian terdahulu (Tahun 2019), peneliti ingin mengembangkan objek penelitian lebih luas yaitu tingkat Sekolah Menengah Pertama (SMP) se Kota Lhokseumawe. Tujuan penelitian yakni untuk mengetahui perbedaan peningkatan kemampuan representasi matematis yang diajarkan dengan menggunakan game matematika online lebih baik secara signifikan daripada siswa yang memperoleh pembelajaran secara konvensional. 


\section{METODE}

\section{Jenis Penelitian}

Penelitian ini merupakan penelitian eksperimen dengan pendekatan kuantitatif dengan rancangan quasi eksperimen. Maka dipilih satu bentuk desain penelitian yaitu "Pre-test and Postes Control-group Design" (Russeffendi, 2010). untuk lebih jelas dapat dilihat desain penelitian tersebut pada gambar di bawah ini:

Tabel 1. Desain Penelitian

\begin{tabular}{|c|c|c|c|}
\hline Kelas & Pretes & Perlakuan & Postes \\
\hline Eksperimen & $\mathrm{O}$ & $X_{1}$ & $\mathrm{O}$ \\
\hline Kontrol & $\mathrm{O}$ & $X_{2}$ & $\mathrm{O}$ \\
\hline
\end{tabular}

Keterangan:

$\mathrm{O}=$ Pretes dan postes

$X_{1}=$ Pembelajaran matematika dengan menggunakan game matematika online

$X_{2}=$ Pembelajaran matematika secara konvensional yaitu tidak menggunakan game matematika online.

\section{Pengumpulan Data}

Data kuantitatif diperoleh dari skor tes siswa dan lembar observasi. Proses penelitian yang telah peneliti lakukan di SMP Negeri 2 Lhokseumawe, SMP Negeri 3 Lhokseumawe dan SMP Swasta Sukma Bangsa Lhokseumawe. SMP Negeri 2 Lhokseumawe tersebut diperoleh data sebanyak 41 siswa Kelas $\mathrm{VIII}_{\mathrm{A}}$ dan $\mathrm{VIII}_{\mathrm{B}}$. Data tersebut tersebar dalam dua kelas, kelas $\mathrm{VIII}_{\mathrm{A}}$ dilakukan pembelajaran dengan menggunakan game matematika online dengan perincian data sebanyak 21 siswa dan kelas $\mathrm{VIII}_{\mathrm{B}}$ diberi pembelajaran konvensional dengan perincian data sebanyak 20 siswa.

Penelitian pada SMP Negeri 3 Lhokseumawe diperoleh data sebanyak 28 siswa Kelas VIII $_{\mathrm{A}}$ dan $\mathrm{VIII}_{\mathrm{B}}$. Data tersebut tersebar dalam dua kelas, kelas $\mathrm{VIII}_{\mathrm{A}}$ dilakukan pembelajaran dengan menggunakan game matematika online dengan perincian data sebanyak 14 siswa dan kelas VIII $_{\mathrm{B}}$ diberi pembelajaran konvensional dengan perincian data sebanyak 14 siswa. Sedangkan penelitian di SMP Swasta Sukma Bangsa Lhokseumawe diperoleh data sebanyak 54 siswa Kelas VIII ${ }_{A}$ dan VIII $_{B}$. Data tersebut tersebar dalam dua kelas, kelas $\mathrm{VIII}_{\mathrm{A}}$ dilakukan pembelajaran dengan menggunakan game matematika online dengan perincian data sebanyak 26 siswa dan kelas $\mathrm{VIII}_{\mathrm{B}}$ diberi pembelajaran konvensional dengan perincian data sebanyak 28 siswa. Penelitian ini diberikan pada materi Statistika dengan jumlah pertemuan sebanyak 10 kali pertemuan.

\section{Analisis Data}

Skor diperoleh dari hasil tes siswa sebelum dan setelah belajar melalui model MMP dengan menggunakan game matematika online dianalisa dengan cara membandingkan dengan skor siswa yang diperoleh dari hasil tes siswa sebelum dan sesudah belajar dengan pembelajaran konvensional. Besarnya peningkatan sebelum dan sesudah pembelajaran secara keseluruhan dihitung dengan rumus 
Penggunaan Media Game Matematika Online untuk Meningkatkan Kemampuan Representasi Matematis Siswa SMP Se-Kota Lhokseumawe, Andriani, Rika Silviani, Lia Rista, Cut Yuniza Eviyanti

gain ternormalisasi (Normalized Gain), yang dikembangkan oleh Hake (Sundayana, 2018) sebagai berikut:

Gain Ternormalisasi menurut Hake (Sundayana, 2018) $=\frac{\text { Skor postest }- \text { Skor pretest }}{\text { Skor ideal-skor pretest }}$

Adapun kriteria skor gain ternormalisasi seperti pada tabel dibawah ini:

Tabel 2. Skor Gain Ternormalisasi

\begin{tabular}{|l|l|}
\hline Skor Gain & Interpretasi \\
\hline $\mathrm{g}>0,7$ & Tinggi \\
\hline $0,3<\mathrm{g} \leq 0,7$ & Sedang \\
\hline $\mathrm{g} \leq 0,3$ & Rendah \\
\hline
\end{tabular}

Data nilai pretes dan postes yang diperoleh dari skor penilaian dibuat kedalam tabel kemudian dihitung rata-rata dan standar deviasinya. Selanjutnya pengolahan data diawali dengan menguji persyaratan statistik yang diperlukan sebagai dasar dalam pengujian hipotesis antara lain uji normalitas dan homogenitas, selanjutnya dilakukan uji-t dengan bantuan software Microsoft excel 2010 dan SPSS 20.

\section{HASIL DAN DISKUSI}

Hasil nilai pretes dan postes kemampuan Representasi matematis dapat ditentukan N-gain, berfungsi mengetahui perbedaan peningkatan kemampuan Representasi matematis siswa. Gain ternormalisasi dihitung dengan membagi selisih nilai postes dan pretes dengan selisih nilai ideal dan nilai pretes. Perhitungan N-gain kemampuan Representasi matematis siswa kelas eksperimen dan kelas kontrol dapat dilihat pada tabel berikut:

Tabel 3. Rata-Rata Data N-Gain Kemampuan Representasi Matematis Siswa

\begin{tabular}{|l|l|l|l|}
\hline Kelas & $\mathbf{N}$ & Mean & Std. Deviation \\
\hline Eksperimen & 61 & .48 & 16.57 \\
\hline Kontrol & 62 & .27 & 12.23 \\
\hline
\end{tabular}

Berdasarkan tabel di atas diperoleh rata-rata N-gain Kemampuan Representasi Matematis siswa belajar dengan menggunakan Game Matematika Online yaitu 0,48 berarti lebih tinggi daripada rata-rata $\mathrm{N}$-gain siswa kelas konvensional yaitu 0,27. Hal ini menunjukkan bahwa kelas eksperimen berada pada kategori sedang, dan kelas kontrol berada pada kategori rendah.

Untuk mengetahui perbedaan peningkatan kemampuan Representasi matematis kelas eksperimen dan kelas kontrol dilakukan uji perbedaan rata-rata, namun terlebih dahulu dilakukan uji normalitas dan uji homogenitas terhadap N-gain kedua sampel tersebut. Hasil perhitungan uji normalitas N-Gain kemampuan Representasi matematis dapat disajikan pada table berikut: 
Tabel 4. Uji Normalitas Data N-Gain Kemampuan Representasi Matematis Siswa

\begin{tabular}{|l|l|l|l|}
\hline \multirow{2}{*}{ Kelas } & \multicolumn{2}{|c|}{ Kolmogorof Smirnof } & \multirow{2}{*}{ Sig. } \\
\cline { 2 - 4 } & Statistic & df & \\
\hline Eksperimen & .107 & 61 & .082 \\
\hline Kontrol & .102 & 62 & .143 \\
\hline
\end{tabular}

Berdasarkan uji normalitas di atas yang telah dilakukan di atas menunjukkan bahwa nilai Ngain kemampuan representasi matematis kelas eksperimen dan kelas kontrol yaitu 0,082 dan 0,143. Nilai signifikansi kedua kelas lebih besar dari $\alpha=0,05$, sehingga dapat disimpulkan bahwa nilai Ngain kemampuan representasi matematis siswa kelas eksperimen dan kelas kontrol berdistribusi normal.

Tabel 5. Uji Homogenitas Data N-Gain Kemampuan Representasi Matematis Siswa

\begin{tabular}{|l|l|l|l|}
\hline Levene Statistic & df & df1 & Sig. \\
\hline 6.090 & 1 & 120 & .015 \\
\hline
\end{tabular}

Berdasarkan uji diatas homogenitas di atas menunjukkan bahwa $\mathrm{N}$-gain kemampuan Representasi matematis kelas eksperimen dan kelas kontrol yaitu 0,15 lebih besar dari $\alpha=0,05$, sehingga mempunyai variansi homogen.

Untuk mengetahui perbedaan peningkatan kemampuan Representasi matematis dilakukan uji t. Uji hipotesisnya adalah "Peningkatan kemampuan Representasi matematis siswa yang diajarkan dengan menggunakan media game matematika online lebih baik secara signifikan daripada siswa yang diajarkan secara konvensional di Sekolah SMP Se-Kota Lhokseumawe".

Rumusan hipotesisnya adalah:

$$
\begin{aligned}
& \mathrm{H}_{0}: \mu_{A 1}=\mu_{A 2} \\
& \mathrm{H}_{\mathrm{a}}: \mu_{A 1}>\mu_{A 2}
\end{aligned}
$$

$\mathrm{H}_{0}$ : Tidak ada peningkatan kemampuan Representasi matematis siswa yang diajarkan dengan menggunakan media game matematika online dengan siswa yang di ajarkan secara konvensional di Sekolah SMP Se-Kota Lhokseumawe

$\mathrm{H}_{\mathrm{a}}$ : Peningkatan kemampuan Representasi matematis siswa yang diajarkan dengan menggunakan media game matematika online lebih baik secara signifikan daripada siswa yang diajarkan secara konvensional di SMP Se-Kota Lhokseumawe.

Hasil pengujian hipotesis di atas dapat dilihat pada tabel berikut ini:

Tabel 6. Uji Perbedaan Dua Rata-rata (Uji-t) Data N-Gain Kemampuan Representasi Matematis Siswa

\begin{tabular}{|l|l|l|l|l|l|}
\hline Uji-t & F & Sig. & t & df & $\begin{array}{l}\text { Sig.(2- } \\
\text { tailed) }\end{array}$ \\
\hline $\begin{array}{l}\text { Equal Variances } \\
\text { Assumed }\end{array}$ & 6.090 & .015 & 7.584 & 120 & .000 \\
\hline
\end{tabular}


Penggunaan Media Game Matematika Online untuk Meningkatkan Kemampuan Representasi Matematis Siswa SMP Se-Kota Lhokseumawe, Andriani, Rika Silviani, Lia Rista, Cut Yuniza Eviyanti

Berdasarkan tabel di atas diperoleh nilai signifikansi sebesar 0,00, nilai-nilai tersebut lebih kecil dari nilai $\alpha=0,05$, dan nilai $t_{\text {hitung }}$ adalah 7,584 lebih besar $t_{\text {tabel }}$ adalah 1,9799. Karena nilai signifikansi lebih kecil dari $\alpha$ atau $t_{\text {hitung }}>\mathrm{t}_{\text {tabel }}$, maka $\mathrm{H}_{0}$ ditolak dan $\mathrm{H}_{\mathrm{a}}$ diterima, dapat disimpulkan bahwa terdapat peningkatan kemampuan Representasi matematis siswa yang diajarkan dengan menggunakan media game matematika online lebih baik daripada siswa yang diajarkan secara konvensional.

Berdasarkan tabel diatas menunjukkan bahwa Peningkatan kemampuan Representasi matematis siswa yang diajarkan dengan menggunakan media game matematika online lebih baik daripada siswa yang di ajarkan secara konvensional di Sekolah SMP Se-Kota Lhokseumawe.

Untuk menganalisis kegiatan guru dan siswa pada kelas eksperimen dan kelas kontrol selama proses pembelajaran matematika. Selama proses pembelajaran dilaksanakan diperlukan lembar observasi untuk mengamati kegiatan guru dan siswa pada kelas eksperimen dan kelas kontrol.

Segala aktivitas guru dan siswa dioservasi oleh observer, dari pertemuan pertama hingga pertemuan terakhir selama 10 kali pertemuan. Analisis data lembar observasi kegiatan guru di analisis dengan menghitung rata-rata dari setiap aspek yang diamati dalam proses pembelajaran dari semua pertemuan. Rata-rata dari setiap aspek yang diamati dalam proses pembelajaran dari semua pertemuan dapat dilihat pada tabel berikut ini:

Tabel 7. Data Rata-rata Pengelolaan Pembelajaran (Aktivitas Guru) SMP Se-Kota Lhokseumawe

\begin{tabular}{|l|l|l|l|}
\hline$X_{\text {rata-rata }}$ Eksperimen & Kriteria & $\begin{array}{l}\boldsymbol{X}_{\text {rata-rata }} \\
\text { Kontrol }\end{array}$ & Kriteria \\
\hline 3,62 & Sangat Baik & 3,54 & Sangat Baik \\
\hline
\end{tabular}

Berdasarkan tabel di atas bahwa rata-rata kemampuan guru dalam mengelola pembelajaran kelas eksperimen dan kontrol selama proses pembelajaran mendapatkan klarifikasi sangat baik. Hal ini berarti dari hasil pengamatan aktivitas guru di kelas menunjukkan bahwa guru mampu melaksanakan pembelajaran dengan sangat baik pada materi statistika dengan menerapkan media game matematika online.

Analisis data lembar observasi kegiatan siswa di analisis dengan menghitung rata-rata dari setiap aspek yang diamati dalam proses pembelajaran dari semua pertemuan. Rata-rata dari setiap aspek yang diamati dalam proses pembelajaran dari semua pertemuan dapat dilihat pada tabel berikut ini:

Tabel 8. Data Rata-rata Aktivitas Siswa SMP Se-Kota Lhokseumawe

\begin{tabular}{|l|l|l|l|}
\hline $\boldsymbol{X}_{\text {rata-rata }}$ Eksperimen & Kriteria & $\begin{array}{l}\boldsymbol{X}_{\text {rata-rata }} \\
\text { Kontrol }\end{array}$ & Kriteria \\
\hline 3,42 & Sangat Baik & 3,55 & Sangat Baik \\
\hline
\end{tabular}

Berdasarkan tabel 8 diperoleh bahwa kemampuan rata-rata aktivitas siswa sangat baik. Peningkatan kemampuan matematis yang menggunakan aplikasi game matematika lebih baikdaripada 
kemampuan matematis siswa yang tidak menggunakan aplikasi game (Hakim \& Sari, 2019). Penelitian yang telah dilakukan (Khatimah et al., 2019) menjelaskan bahwa game dapat memberikan pengalaman nyata yang membantu siswa pemahamannya untuk meningkatkan kognitif dan pemahaman siswa. Penerapan game memberikan pengaruh positif terhadap perkembangan stimulus siswa, meningkatkan kemampuan representasi siswa serta memberikan suasana yang menyenangkan bagi siswa. (Ni Putu et al., 2014) memberi kesan bahwa game merupakan manifestasi penyesuaian, salah satu dasar proses-proses mental menuju pada pertumbuhan intelektual dan game merupakan suatu mekanisme penyesuaian yang penting bagi perkembangan intelektual siswa dalam belajar. Sehingga media game matematika online dapat membantu menciptakan kegiatan yang menarik dalam pembelajaran sehingga belajar menjadi menyenangkan dan efektif.

\section{KESIMPULAN}

Berdasarkan hasil analisis data diperoleh nilai signifikansi sebesar 0,000, nilai tersebut lebih kecil dari nilai $\alpha=0,05$, dan nilai $t_{\text {hitung }}$ adalah 7,584 lebih besar $t_{\text {tabel }}$ adalah 1,9799. Karena nilai signifikansi lebih kecil dari $\alpha$ atau $t_{\text {hitung }}>t_{\text {tabel }}$, maka $\mathrm{H}_{0}$ ditolak dan $\mathrm{H}_{\mathrm{a}}$ diterima, dapat disimpulkan bahwa peningkatan kemampuan Representasi matematis siswa yang diajarkan dengan menggunakan media game matematika online lebih baik secara signifikan daripada siswa yang diajarkan secara konvensional di SMP Se-Kota Lhokseumawe. Hasil observasi aktivitas guru dan siswa kelas eksperimen dan kontrol selama proses pembelajaran mendapatkan klarifikasi sangat baik. Sehingga dapat disimpulkan bahwa siswa yang mendapatkan pembelajaran matematika dengan penerapan media game matematika online terjadi peningkatan kemampuan representasi matematis lebih baik daripada siswa yang memperoleh pembelajaran konvensional.

\section{UCAPAN TERIMA KASIH}

Terima kasih penulis ucapkan kepada DRPM Kemenristekdikti yang telah mendanai penelitian ini, LLDIKTI Wilayah XIII, ketua dan jajaran STKIP Bumi Persada Lhokseumawe, Kepala dan Jajaran SMP Sekota Lhokseumawe yang telah berpartisipasi dalam penelitian ini, begitu banyak membantu penulis dalam menyiapkan kebutuhan penelitian dan mengawasi proses penelitian sehingga penelitian berjalan lancar dan maksimal.

\section{REFERENSI}

Abdillah, I., \& Sudrajat, D. (2014). Pengembangan Permainan Ular Tangga pada Pembelajaran Matematika untuk Meningkatkan Prestasi Belajar Siswa di SDN Majalengka Wetan VI. Jurnal Online ICT-STMIK IKMI.

Andini, M., \& Yunianta, T. N. H. (2018). The Development of Borad game "The Adventure Of Algebra" in The Senior High School Mathematics Learning. Al-Jabar: Jurnal Pendidikan Matematika, 9(2), 95-109. https://doi.org/10.24042/ajpm.v9i2.3424

Chen, C. J. (2016). Mathematical Representations. Elements of Human Voice, 97-98. 
Penggunaan Media Game Matematika Online untuk Meningkatkan Kemampuan Representasi Matematis Siswa SMP Se-Kota Lhokseumawe, Andriani, Rika Silviani, Lia Rista, Cut Yuniza Eviyanti

https://doi.org/10.1142/9789814733908_others02

Hakim, D. L., \& Sari, R. M. M. (2019). Aplikasi Game Matematika Dalam Meningkatkan Kemampuan Menghitung Matematis. Jurnal Penelitian Dan Pembelajaran Matematika, 12(1), 129-141. https://doi.org/10.30870/jppm.v12i1.4860

Hamidah, D., \& Hakim, Z. A. (2016). PERMAINAN MATEMATIKA ONLINEBEADS ON STRING UNTUK BELAJAR MATEMATIKA YANG BERMAKNA DAN MENYENANGKAN DI MADRASAH IBTIDAIYAH (MI). Cendekia: Jurnal Kependidikan Dan Kemasyarakatan. https://doi.org/10.21154/cendekia.v14i1.552

Ilyas, M., Agung, S., Lihu, I., \& Palopo, U. C. (2020). Development of a mathematics instructional media by utilizing geogebra to enhance junior high school students' Higher order thinking skills. 8(1), 41-53.

Khatimah, H., Johar, R., \& Abidin, T. F. (2019). Upaya Guru Menggunakan Game dalam Pembelajaran Matematika. Jurnal Peluang, 7(1), 13-21. https://doi.org/10.24815/jp.v7i1.13751

Ni Putu, M., Minarti, N. M. A., \& Utami, K. C. (2014). Hubungan Bermain Game Online dengan Prestasi Belajar Matematika Anak Usia Sekolah Kelas V di Sekolah Dasar Saraswati I Denpasar tahun 2014. Program Studi Ilmu Keperawatan Fakultas Kedokteran Universitas Udayana.

Patahuddin, S. M., \& Rokhim, A. F. (2009). Website Permainan Matematika Online Untuk. Jurnal Pendidikan Matematika, 3(Desember).

Rangkuti, A. N. (2013). Representasi Matematis. Logaritma.

Sabirin, M. (2017). Representasi dalam Pembelajaran Matematika. Jurnal Pendidikan Matematika, 1(2), 33. https://doi.org/10.18592/jpm.v1i2.49

Siregar, N. R. (2017). Persepsi Siswa Pada Pelajaran Matematika: Studi Pendahuluan Pada Siswa yang Menyenangi Game. Prosiding Temu Ilmiah X Ikatan Psikologi Perkembangan Indonesia.

Sulastri, S., Marwan, M., \& Duskri, M. (2017). Kemampuan Representasi Matematis Siswa SMP Melalui Pendekatan Pendidikan Matematika Realistik. Beta Jurnal Tadris Matematika. https://doi.org/10.20414/betajtm.v10i1.101

Wibowo, A. (2020). The use of online mathematics game for portfolio assessment of elementary school students. Math Didactic: Jurnal Pendidikan Matematika. https://doi.org/10.33654/math.v6i1.909

Yanni, H. (2019). Peningkatan kemampuan representasi matematis dan motivasi siswa melalui implementasi Lemang Aceh berbasis game Matematika online. 1(1), 108-113.

Zhe, L. (2012). Survey of Primary Students' Mathematical Representation Status and Study on the Teaching Model of Mathematical Representation. Journal of Mathematics Education, 5(1), 6376. 